\title{
Urban Drummers: The Experience of Playing, Being and Feeling in Community
}

https://doi.org/10.21814/uminho.ed.51.5

Fábio Marques

Centro de Estudos de Comunicação e Sociedade, Instituto de Ciências Sociais, Universidade do Minho, Braga, Portugal https://orcid.org/0000-0001-7151-2925

ffreitasmarques@gmail.com

Jean-Martin Rabot

Centro de Estudos de Comunicação e Sociedade, Instituto de Ciências Sociais, Universidade do Minho, Braga, Portugal http://orcid.org/0000-0001-7688-3186 jmrabot@ics.uminho.pt

Helena Pires

Centro de Estudos de Comunicação e Sociedade, Instituto de Ciências Sociais, Universidade do Minho, Braga, Portugal https://orcid.org/0000-0002-5533-4687 hpires@ics.uminho.pt

\section{Abstract}

Marching percussion groups are recurrent elements in urban festivities in Brazil and Portugal. Associated with a diversity of traditions, the groups mobilise dozens of players and modify the soundscape of the cities. This article proposes a theoretical discussion about this type of practice, focusing on the meanings its participants give to this musical. Aligned with the perspective of cultural studies, from a bibliographic review and a mapping of 
percussion groups activity in the cities of Fortaleza and Braga, we discuss some definitions related to the group's practice and organisation. Some of the topics discussed include the appeal to the notion of community (Amit, 2002; Anderson, 1983/2008; Hall, 1993; Mocellim, 2010) and traditional practices in contemporary times (Giddens, 1990/1996); the informal teaching model based on musical practice and classified under the concept of "community music" (Higgins, 2012; McKay \& Higham, 2012; Veblen, 2008); and issues related to sociality (Bauman, 2000/2001; Fernandes, 2005; Maffesoli, 1988/1998), identity (Hall, 1992/2006) and performance (Schechner, 2013) in postmodernity. Focused on the percussion groups, we defined a form of organisation - as a group of teaching and collective musical practice, with a master, a reference in tradition and a strong appeal to the sense of community. We also defined a practice - as hybrid performances, which articulates sacred and secular ritual elements with leisure activities, artistic expressions and the cultural industry.

Keywords

drums, festival, identity, popular music, sociality

\section{Introduction}

Popular festivities include musical performances as an indispensable element of animation. They are present in a programmed and well-defined way, on the stages set up by the municipalities, where hired artists are presented, or in improvised spaces for the commemorative parades and street group performances. But also, in a less controlled way, music occupies squares, streets and sidewalks, as street artists at improvised concerts or marching bands, which snaps their batucadas or metal orchestras on random routes. In different ways, music occupies and transforms public space.

In contemporary times, as part of annual calendars in large and small cities, popular festivals have a strong appeal to local identities, guided by traditions - although often created or revived recently - but also by appealing to novelty, adding new elements, or transforming ancient forms and practices.

The percussion groups, aimed in this article, have become popular in different contexts, mobilising many musicians (professionals and, especially, amateurs) who started to include the musical practice as an element of their daily lives - by learning how to play the instrument, rehearsing and 
performing. Groups also play an important role in establishing social networks, promoting new ways of occupying and experiencing the city and shaping different ways of being and showing themselves.

Based on a bibliographic review and a preliminary mapping of groups working in the cities of Fortaleza (Brazil) and Braga (Portugal), we propose in this article to discuss concepts and approaches for the understanding of the meanings attached to these cultural activities - the marching percussion groups - in contemporary cities and festivals.

Our goal is to problematise the experience in these groups from the participants' perspective. As laid out in this opening, to animate is just a small issue among the debate around musical practices and listening to popular festivals. In a short period of days, the daily lives of cities are modified in such a way that changes the uses and meanings we give to the different spaces, the routines of those who frequent them, the forms of perception, and the experience the daily life. Music acts in these transformations.

This work integrates a doctoral research project, inscribed in the perspective of cultural studies, witch stress issues related to identity, sociality and performance of percussion practitioners in marching percussion bands in Fortaleza and Braga.

The investigation also fits into the activities of Passeio - Platform for Urban Art and Culture (http://www.passeio.pt/), a project developed within the scope of the Communication and Society Research Centre (CECS) of the University of Minho. Passeio is an intervention platform in communication sciences, which adopt an interdisciplinary approach to urban culture through the collection, organisation, and dissemination of collective memories, artistic expressions, and cultural activities of everyday life (Correia \& Pires, 2018; Correia et al., 2017).

\section{Performance and Ritual}

Throughout the 20th century and the beginning of the 21st century, Western societies have undergone several changes in the way of being, living, and socialising, including industrialisation, technological advances, and the growth of cities as a backdrop.

There was an intense mediatisation of consumption in the musical field, formatting music as a product, establishing a transnational phonographic 
industry, radio and TV broadcasts, and, more recently, the diffusion of digital formats via the internet. In a parallel process, music also takes shape in the streets, with the establishment of a live music market consolidated in commercial concerts and festivals, public parties, or informal performances, such as music circles between friends. For Janotti and Pires (2011), media consumption and live music complement. They are connected as elements of the same cultural network (Janotti \& Pires, 2011, p. 9).

By focusing on street musical performances and percussion groups, we can distinguish different structures of groups and meanings associated with their practices. It is the case with music as entertainment/art, in which its actors are essentially positioned as artists/musicians, and they consider compositions or its playing as the product of their activity. It is markedly an expression with the author's signature or the group. Another possibility is to conceive music as a traditional cultural manifestation, considered a symbolic/ritual performance. It is to say music materialises a collective expression, perceived more as a symbol and aesthetic expression of a collectivity than an artistic composition.

Guilds such as samba schools or bombos groups are, as a rule, associated with collective and traditional festivities. Although they can play commercial songs composed by well-known authors and part of a cultural industry, their performance is strongly linked to collective practice, rites, dances, and sounds that have become cultural symbols of certain groups over time.

The very origin of studies of popular festivals by the social sciences highlights this collective and symbolic character when folklore - dances and music - was extolled as an aesthetic expression of the essential values of isolated communities, which would materialise their identity, practices, and traditions. In other words, their culture (Storey, 2003).

What is the role of these cultural manifestations in contemporary societies? What are the meanings and uses of a maracatu or bombos performance in the contexts and dynamics of present cities and societies? Is there a real distinction between what is symbolic/collective ritual and what is just entertainment/art? How do these elements come together? Before moving on in this direction, let us discuss the concept of performance itself and its articulating elements.

Performance studies consider that the basis of any performance is ritual and that it invariably lies between utility and entertainment. For Schechner (2013), the meanings of rituals are varied and, at times, contradictory: 
performance originates in the need to make things happen and to entertain; to get results and to fool around; to show the way things are and to pass the time; to be transformed into another and to enjoy being oneself; to disappear and to show off; to embody a transcendent other and to be "just me" here and now; to be in trance and to be in control; to focus on one's own group and to broadcast to the largest possible audience; to play in order to satisfy a deep personal, social, or religious need; and to play only under contract for cash. (p. 81)

Whether in the arts, sports, or everyday life, any performance consists of ritualised gestures and sounds embedded with meaning and repeated even when someone improvises. "Even when we think we're being spontaneous and original, most of what we do and utter has been done and said before - by us even" (Schechner, 2013, p. 52). Understanding the nature of rituals, therefore, is important for our debate.

Drawing a parallel with Saussure's linguistic metaphor, music, like language, does not constitute an individual's original expression, but a way to activate the "vast range of meanings which are already embedded in our language and cultural systems" (Hall, 2006, p. 40).

In short, rituals are a defined and stylised way of acting, embedded with meanings, and able to communicate something and be an event itself (Rappaport, 1979, as cited in Schechner, 2013, p. 53).

Schechner (2013) divides rituals into two broad categories: the secular, associated with ordinary acts, social events, the arts, sports and daily life; and the sacred, related to spirituality or religious beliefs.

Most of the rituals, Schechner (2013) reinforces, mix elements from both categories. Although they are distinct, they can hardly be isolated from each other. Victor Turner $(1969$, as cited in Schechner, 2013) uses the concept of "liminal" to define this hybrid characteristic (p. 66).

The author also proposes a new possibility of hybridism that rises in contemporary times. He called it "liminoid". In addition to the two liminal combinations (sacred and secular), the liminoid rituals add elements from the arts (positioning themselves as artistic activities), the entertainment industry and fun and leisure performances. "Generally, liminoid activities are voluntary, while liminal rites are obligatory” (Schechner, 2013, p. 67). 
Focusing on the groups we intend to study, it is possible to say that they are ritualised collective practices, full of symbolism, with elements of the sacred, as the case of maracatu, and festive ones, such as the bombo groups and samba schools.

In this way, we point some possible manners to understand the meanings of these groups in contemporary cities: as liminoid rituals, they articulate ritual functions, with secular and/or sacred nature (liminal), entertainment goals, recreation, and even elements of popular music as art.

\section{Music Education and Community}

Before moving on to the debate on the meanings of these practices in contemporary times, we may discuss the general structure of a street percussion group. In the mapping carried out in the cities of Braga and Fortaleza, 31 groups and six different manifestations were identified. The Brazilian city has seven active groups of maracatu, and part of them have existed for decades, as Maracatu Az de Ouro (since 1936); and others, created in the 21st century, such as Maracatu Solar and Maracatu Nação Fortaleza. Maracatu is one of the main references in traditional musical performances in the city.

Several groups not recognised as traditional were further included in the mapping, as part of the range of carnival guilds: the afoxés, with four groups; the samba schools, with seven groups; and the baterias and general percussion groups, with three bands.

In Braga, music is part of popular traditional performances such as folkloric ranches and toccatas, which parade in festivities such as the Holy Week and São João (Saint John's Eve). Both groups' places percussions as part of their musical instrumentation, but with a secondary role. However, the percussive practice is marked in the bombos (bass drum groups), also called "Zés Pereiras" - considered a genuine Portuguese traditional folk band.

There are 10 active bombo bands just in Braga. Part of them are linked to secondary schools or scout groups, such as Tim Ca Bombo; or neighbourhood associations, such as the Grupo de Bombos and Cabeçudos da Rusga de S. Vicente group; and university associations, as Bomboémia and iPUM (University Percussion of Minho). A national mapping carried out by the Toca a Rufar (www.tocarufar.com) project identified 350 groups spread across 30 districts in Portugal and six other European countries. 
Among the common characteristics shared by groups from both cities besides the percussion as an instrumental base, we can highlight the great formations (with more than 20 instrumentalists) and the joint musical practice that has in public performance a primary element. They also share issues such as hierarchical ordering, which provides for the intervention of a master or teacher, the active participation of group members in the various stages of music-making, and the appeal to the idea of community.

We can also point out the liminoid character of these activities as common traits and the link between performances and popular parties. It is necessary, as well, to discuss two other possible characteristics: (a) they mobilise amateur musicians, therefore excluding professional groups that work properly in the artistic market, in major concerts and music festivals (we will problematise this characteristic shortly); (b) they organise themselves as a kind of community for cultural practice.

On the first topic, we run into a complexity that is characteristic of the present times: these two categories, amateurs and professionals, are confused or mixed in the practice of the group. There is no such clear separation. Even if we consider the way the percussionists themselves recognise each other, we realise that the groups aggregate from beginning practitioners, who have barely started to learn an instrument, to other amateurs with some experience and self-called professional musicians.

In principle, how the groups are structured as communities for cultural practice is also notably hybrid. They act in popular celebrations, moved by a community sense, as representatives of traditions, as cultural producers, inserted in a local artistic and cultural circuit, financed by public notices, and so forth. It is recurrent for the same group to participate in street communitarian performances and formal stage concerts, whether at private or public parties, festivals; or to record discs, sell items with the group's brand, and so forth.

To discuss the measurement of success attributed to professional musicians, Becker (1991/2008) lists a series of parameters, including the spaces where they play, their remuneration, hours of work, and the community's recognition. Perhaps all these elements, to some extent, are also a reference for street percussion groups.

In an attempt to better characterise the form of organisation and performance of these groups, we chose to use the concept of "community music" 
(Higgins, 2012; McKay \& Higham, 2012; Veblen, 2008). With relevant works published in English-speaking countries, especially since the 2000s, the concept has paved the way for a field of research linked to music education.

Although some authors recognise the difficulties of a single definition of what $\mathrm{CM}$ is, due to the diverse use and multiple issues it involves and the initiatives thus framed, names like Veblen (2008) seek to systematise it from a specific music teaching practice.

For Veblen (2008), based on the premise that everyone can create and play music, the groups share some characteristics: they involve a program of active participation at different levels, to create, to perform, to improvise; they are integrated in cultural activities (festivities, ceremonies, concerts); they encourage music as a socially relevant activity, for example, acting to bring people together and contribute to the constitution of their individual and collective identities; they have proposals that are comprehensive enough to encompass diverse objectives (such as social inclusion, integration of immigrants, cultural preservation, religious practice, etc.); bring together people with voluntary participation and the possibility of diverse activities (such as observers, participants, creators or leaders); they appeal to a sense of community in its various possibilities, for instance "geographically situated, culturally based, artistically concerned, recreated, virtual, imagined or otherwise" (p. 8).

To overcome broad descriptions, as in Veblen (2008), and exclude similar activities from what is conceived as CM, Higgins (2012) systematises three possibilities of current uses of the term: "(1) music of a community, (2) communal music-making, and (3) an active intervention between a music leader or facilitator and participants" (p. 3).

Higgins (2012) considers the uses quite generic and centred on an idea of the local community, which shares identity, traditions, aspirations and social interactions. Music of a community refers to music recognised as belonging to a community, culturally located. It is the result of a given local culture. The second point - communal music-making - deals with participation (as a practitioner or audience) in activities aimed at this community's music, whether within the community itself or not, as would be the case of meetings in migrant groups to play their traditional genres. The last possibility pointed out by Higgins (2012) refers to the definition that the author intends to adopt as CM: 
the third perspective suggests that community music may be understood as an approach to active music making and musical knowing outside of formal teaching and learning situations. By formal, I mean music that is delivered by professionals in schools, colleges, and other statutory organizations through formalized curricula. From this third perspective, community music is an intentional intervention, involving skilled music leaders, who facilitate group music-making experiences in environments that do not have set curricula. (p. 4)

Through this educational bias, we, therefore, have three main points that typify this practice: informal group teaching, active participation of members in making music (which implies the participants themselves decide to be part of the group and each one is responsible for being there, learning, playing) and the intervention of a facilitator (in this case, the figure of the percussion master, more experienced musician or coordinator).

Even so, there is a range of possibilities sheltered by the CM's hat. Addo (2002, as cited in McKay \& Higham, 2012, p. 4) lists possibilities such as music groups in community centres, retirement homes, prisons, extra-curricular projects with children and youth, choirs, orchestras, community bands, martial bands. We are, therefore, looking for a cut within this universe, approaching the percussion groups linked to traditions and popular festivals.

In an attempt to narrow this focus, we added to the concept of CM, by Higgins (2012), elements such as street performance; the preponderance of percussion - thus excluding martial marching bands, fanfare, choral singing - and the strong association of the group with one or more cultural manifestations.

It is possible to find common elements between $\mathrm{CM}$ and the so-called communities of practice. In short, both share the idea of learning supported by the appeal to the sense of community. The difference, however, is that the communities of practice have a more horizontal dynamic, without the need for a master or teacher, and have as a binding element the intention to learn through the sharing of information and joint practice.

The purpose of using the bibliography on $C M$ is not to reduce cultural events to musical teaching projects or to necessarily group them under a single model of organisation, but to identify common points that bring groups together and allow us to compare various kinds of popular manifestations in search of common meanings. 
In addition to the musical dynamic itself, another key issue for understanding these groups is the notion of community (and what follows from it). Although there is no single definition adopted for the concept of community in the social sciences, some elements are recurrent in the attempt to conceptualise it: to establishes a community, a collectivity is needed, where values and world views are shared, social relationships, emotional bonds, moral commitment are established, and there is a certain stability of these relationships in time and space (Mocellim, 2010, p. 106). In this sense, the American sociologist Robert Nisbet (1967, as cited in Mocellim, 2010) defines community as a traditional way of life in opposition to the rationalism and individualism of modernity:

community is a fusion of feelings and thoughts, of tradition and commitment, of adherence and volition. ( ... ) Its archetype, both historically and symbolically, is the family, and in almost every type of true community, the nomenclature of the family is important. (p. 107)

Similarly, for Weber (1922/1987, as cited in Mocellim, 2010, p. 110), the community is a social relationship based on solidarity resulting from emotional or traditional bonds between its members. Tönnies (1995, as cited in Mocellim, 2010, p. 110) opposes the community to the idea of society. While society admits fragmentation and even opposition between groups, the community refers to something more cohesive and positive (Mocellim, 2010).

The metropolis is an expression of individualism, although it comprises many people and groups. In modernity, rationality and novelty gain ground at the expense of the idea of tradition - which refers to permanence, to the repetition of practices shared by the group, to emotional ties that unify a collectivity.

Paradoxically, it is precisely by accentuating the process of urbanisation and multiplication of metropolises in complex societies that the notion of community gains relevance. As highlighted by Vered Amit (2002), unlike societies called "primitive", unitary and isolated, in the contemporary world, the community resonate "as a limited subunit, inextricably but also problematically embedded in wider social and cultural contexts" (p. 2).

Amit (2002) advocates displacing the notion of community as a well-defined social form, dependent on physical limits or long-term relationships, to conceive it as an "idea or quality of sociality" (p. 3). In this sense, we arrive at the notion of community proposed by Stuart Hall and Raymond Williams. 
We assume the centrality of communication by adopting a concept of culture as a process linked to the meaning of the world, actions, relationships, experiences - of giving and apprehending meanings. Through communication, meanings are shared, creating a sense of community. Based on Raymond Williams' texts, Hall (1993) thinks of the notion of community as something dynamic, forged in a constant process, inseparable from communication and the notion of culture itself. For Williams (1961, as cited in Hall, 1993):

human community grows by the discovery of common meanings and common means of communication ( ... ). Thus our descriptions of our experience come to compose a network of relationships, and all our communication systems, including the arts, are literally parts of our social organisation. The selection and interpretation involved in our descriptions embody our attitudes, needs and interests, which we seek to validate by making them clear to others. At the same time the descriptions we receive from others embody their attitudes, needs and interests, and the long process of comparison and interaction is our vital associative life. (p. 352)

To Hall (1993), the sense of community depends more on a constant renewal of ties, values, memories, interaction - whether face-to-face or not - than cohesion and permanence. In this sense, Benedict Anderson's (1983/2008) notion of imaginary communities provides an enormous contribution.

For Anderson (1983/2008), the greater circulation of information, stories, common references, driven by the media, allowed people to share identities and lifestyles. Even if they lived in distant places and did not have the same social nuclei or even knew each other, they shared a common feeling of connection, of belonging to the same community. For Anderson $(1983 / 2008)$, the clearest example is the idea of a nation, classified as a large, imagined community. The sense of community would therefore go beyond the immediate relationship.

However, Amit (2002) points out that Benedict's work becomes even more potent when associated with Michael Herzfeld's concept of "cultural intimacy". Amit (2002) argues that the author demonstrates how imagined feelings of belonging gain strength in everyday life. We conceive veracity to this feeling of belonging (Amit, 2002, p. 8) from everyday life and face-to-face relationships. Although not all elements of a given community are known, and even if they are spread out, the feeling of belonging materialises in the coexistence between parties who imagine themselves to be members of a community. At this point, as we will see later, we 
approximate the idea of community, of music in the community, of what Maffesoli (1988/1998) called "tribe".

\section{From Music Groups to Tribes}

Hitherto, we have defined some essential points to understand musical percussion groups, their practices and general contexts: in form, constituted as more or less formalised groups, guided by a teacher, linked to a popular tradition; and in practice, centred on learning, public performing, and appealing for community action, anchored in aesthetic and emotional sharing.

Henceforth, we can discuss the meanings of these group practices and their links to traditions and popular festivals in contemporary times.

As Giddens argues (1990/1996),

in traditional societies, the past is honoured and symbols are valued because they contain and perpetuate the experience of generations. Tradition is a means of handling time and space, which inserts any particular activity or experience within the continuity of past, present and future, these in turn being structured by recurrent social practices. (p. 37)

Modern societies, however, are marked by constant and rapid change, calling into question the permanence of traditional knowledge, practices and values. National cultures are increasingly hybridised, entangled and interconnected (Welsch, 1999), accentuating this process in postmodernity. There is a growing acceleration in the flow of information, consumer goods and people around the globe, in what Harvey (1989/2008) called the compression of space and time.

For theorists like Bauman (2000/2001), this postmodernity is liquid, marked by the impermanence of things, weakening institutions, superficiality and individualism. The logic of consumption guides social relations (Bauman, 2000/2001).

What would be the role of collective performative activities in traditional practices in this new context? How do practices forged in past community rituals remain current (gaining prominence and mobilising more and more people in contemporary cities)? Who are these subjects who participate in this type of activity, and what meanings are attributed to it? 
We start by highlighting two distinct, albeit interconnected, issues: being together (sociality) and showing the self (identity). Maffesoli (1988/1998) makes a counterpoint to thinkers like Bauman, rejecting the idea of a tendency towards individualism. In response to individualism and the so-called crisis of values, or the great narratives, the author proposes a propensity for association in small groups, which he calls "tribes", alluding to the sharing of beliefs, values, identity references and utopias.

On the opposite to the idea of the tribe as isolated, well-defined and longlasting societies, postmodern urban tribes are ephemeral, appear and fall apart, are fluid, constantly changing, and have blurred boundaries.

The individualism and the logic of consumption guiding social relations, argued by Bauman (2000/2001), are combined with a gregarious need, a search for recognition and achievement of the individual in the collective.

As cities grow larger and larger, housing more and more people from different parts, with a multiplicity of cultural references, tribes bring together groups and foster the idea of being part of a community. Postmodern tribes share affections, memories, sensitivities.

For Maffesoli (1988/1998), studying everyday life involves identifying solidarity networks forged in the face-to-face relationship, the sharing bounds, the collective experiences and memories, which can form true affective nebulae and culminate, in some situations, with an emotional fusion of individuals. Schutz (1951, as cited in Maffesoli, 1988/1998) refers to making music together as an activator of this fusion, as an epiphany in which the collective feeling, the presence of "we", stands out (p.103).

The common experiences, the shared feelings, the affections cement the relationships built and reinforced in the ephemeral of everyday experience. Maffesoli (1988/1998) suggests a kind of "civil religion", in which the individual starts to make sense for the collective. It is in the collective that he finds his strength.

The percussion groups as a context of sociality, in this sense, would be an agent of sharing, with a strong gregarious appeal, fostering experiences in the urban space. When linked to celebrations and popular performative activities, whether from a local tradition or not, the practices in the groups appeal to the idea of sharing affinities and community belonging. They serve as expressions of localisation of the group and the tribes amid a complex and fragmented society. 
The articulation between groups linked to the same cultural expression and other groups and musical practices (and other artistic languages), in each context, leads us to problematise not only the dynamics of the group in the social environment but its connections with other groups, the local context in which the cultural practice takes place, and its integration into the urban space. How do they occupy and transform the city spaces? Understanding the universe of percussion practitioners, therefore, involves the notion of musical/cultural scene (Bennett, 2004; Janotti, 2013; Silver \& Clark, 2016; Straw, 1991, 2015).

Shortly, as proposed by Will Straw (1991, 2015), the scenes are contexts in which cultural activities become visible and decipherable, "by rendering it public, taking it from acts of private production and consumption into public contexts of sociability, conviviality and interaction" (Straw, 2015, p. 483).

The study of music scenes is closely linked to the notion of subcultures and tribes, relating cultural practice to space. The "scene", as a concept, guides the study of contexts in which a common cultural practice is established, inscribed in a territory where several other groups and practices can cohabit (Janotti, 2013).

It is worth mentioning here the contribution of Andy Bennett (2004), who points out the possibility of these practices having strictly local expressions, restricted to a city, neighbourhood, and so forth, but also - and in a very systematic way - trans-local, interconnected with other urban spaces, with the circulation of artists, public, and so forth; and virtual, with a strong presence and interactions on the internet.

The notion of "scene" articulated with the dynamics of socialisation in the groups leads us to another topic: identity performances. Unlike isolated or stable and atomised societies, in postmodern tribes, these associations are not dictated by cultural origin or by geography. They are part of complex processes of identity formation in which the subject chooses which ties to strengthen which groups to join.

Identities, previously fixed and coherent, anchored in broad and stable categories such as social class, nationality or race, are now in crisis, displacing the subject's social place. The latter no longer has a fixed and unified identity, becoming fragmented, partial, and capable of articulating different, sometimes contradictory, identity references (Hall, 2006, p.23). 
Ultimately, traditions serve as a plot and aesthetic forms of construction, legitimation and expression of identities. They are part of identity processes, as an expression of what defines the subjects, although often mystified, "legendarily narrated, as simple archaic procedures", as Canclini (1984, as cited in Martín-Barbero, 1997, p. 30) points about national cultures.

Articulating identity and sociality, Fernandes (2005) proposes the concept of "aesthetic-communicative power", according to which these associations, this desire to be together, is not only rationalisable but sensitive, driven by an aesthetic power. For the author, it is aesthetics

that brings together and communicates the different communities within the globality, in which communication, by whatever means, is the guarantee of the most primary being-together, regardless of social contracts and deliberative actions. (Fernandes, 2005, p. 78)

The subject with a "de-centred" identity of late modernity, as summarised by Stuart Hall (1992/2006), creates strategies for stabilising and anchoring his identity. Conscious or not, he seeks in the collective - in the tribes, as Maffesoli (1988/1998) tells us - social legitimation. He activates the feeling of belonging in the group and adheres to collective values and practices, which coincide with an identity that he claims for himself.

However, this identity claimed by the group is also malleable and can change according to this subject's interests or situation. It is not an attempt to return to a past situation of a stable identity but a search for stability aligned whit the subject's present wishes. It is therefore susceptible to the volatility of time.

\section{Batuqueiro's Enunciation: Attempting a Conclusion}

It is important to problematise the public character of their presentations to understand musical practices in percussion groups. Musical performance as an expression of identity goes through individual bias as a form of public representation of the self (Goffman, 1975/2002). We can investigate the expressions of that self in the daily relations of the group, the characters that take place in the different moments of conviviality, in the rehearsal meetings, percussions classes, and during the performances, when the public joins the scene. Beyond this, part of this dynamics occurs in post-presentation, at socialising situations, as group parties, bars meetings: "when an individual appears before others, there is, in general, some reason that 
leads him to act in a given way in order to give the kind of impression he intents" (Goffman, 1975/2002, p. 13). The shared experience of a performance in the percussion group and music is a practice of showing yourself, an act of projecting yourself to others.

The group is not just a way to learn music and get to know different popular cultures, nor meet people and live with them. It is a gateway to a cultural scene in a city, to feel integrated into a community, legitimise the subject as an actor in these contexts and publicise its experience.

If, on the one hand, there is massification and standardisation of experience by consumption, the "tribes" complexify the meanings and relationships in postmodernity, appropriating the massive and transforming it. The performances in percussion groups are consolidated as liminoid rituals, with voluntary adherence and articulating diverse logics, such as community performance, the arts and selling music as a product. Participation in these groups is desired/offered and bought/sold.

In this article, we move forward to define a type of musical practice that belongs to different urban contexts and is associated with different cultural expressions. Focused on percussion groups, we define a form/structure organised as a group of collective musical learning and performing, including a master or musical leader, anchored in a popular tradition and appealing to the sense of community; and a practice - as hybrid performances, which articulate sacred and secular ritual elements with the logic of leisure activities, artistic expressions and commercial activities.

We point out possible ways to understand these practices in contemporary cities, in which the consumption of popular music occurs through musical practice itself. The boundaries between production and consumption are blurred. We can place these drummers in the category of so-called "prosumers" (Canclini et al., 2012, as cited in Herschmann \& Pegoraro, 2017, p. 83).

Whether on their repertoire, the places they perform, or the discourse they evoke on traditional practices, they are linked. The percussion groups add a strong symbolic charge to the musical practice. Group practice is conceived in the appeal to these symbolisms, drumming, and public and collective performances. From articulating these multiple elements, identity and gregarious appeal of affective sharing occur.

Percussion groups - and the cultural scenes in which they are consolidated - works as sources of multiple mediations, as proposed by Martín-Barbero 
(1997) and Orozco Gómez (2005). They are spaces for the mediation of community/commercial logics, ritual/artistic/commercial, between past/ present times, between the culture of the others/ours.

Instead of analysing only the musical dynamics and symbolic contents evoked by these performances, we propose to understand these practices from everyday life, investigating their meanings in the daily lives of percussionists.

Translation: Fábio Marques

\section{Acknowledgements}

The project is supported by the FCT - Fundação para a Ciência e a Tecnologia, I.P., through a PhD scholarship (SFRH/BD/147043/2019) within the scope of the Doctoral Program in Cultural Studies of the University of Minho. This work is also supported by national funds through FCT - Fundação para a Ciência e a Tecnologia, I.P., under project UIDB/00736/2020 (base funding) and UIDP/00736/2020 (programmatic funding).

\section{References}

Amit, V. (Ed.). (2002). Realizing community. Routledge.

Anderson, B. (2008). Comunidades imaginadas: Reflexões sobre a origem e a difusão do nacionalismo (D. Bottman, Trans.). Companhia das Letras. (Original work published 1983)

Bauman, Z. (2001). Modernidade líquida (P. Dentzien, Trans.). Zahar. (Original work published 2000)

Becker, H. S. (2008). Outsiders: Estudo de sociologia do desvio (M. L. de A. Borges, Trans.). Zahar. (Original work published 1991)

Bennett, A. (2004). Consolidating the music scenes perspective. Poetics, 32(3), 223-234. https:// doi.org/10.1016/j.poetic.2004.05.004

Correia, M. L., \& Pires, H. (2018). Entre narrativas e entre passeios: Uma aproximação à etnografia do intervalo. In J. Teixeira (Ed.), Espaços, culturas urbanas e contemporaneidade (pp. 135-158). Centro de Estudos Lusíadas da Universidade do Minho; Húmus.

Correia, M. L., Pires, H., \& Andrade, P. (2017). Passeio, passante, passeante. Uma plataforma de arte e cultura urbana. Revista Lusófona de Estudos Culturais, 4(1), 167-183. https://doi. org/10.21814/rlec.184 
Fernandes, C. S. (2005). Sociabilidade, comunicação e política: A rede MIAC como provocadora de potencialidades estético-comunicativas na cidade de Salvador [Doctoral dissertation, Universidade Federal de Santa Catarina]. Repositório Institucional da UFSC. https://repositorio. ufsc.br/handle/123456789/87169

Giddens, A. (1996). The consequences of modernity. Polity Press. (Original work published 1990)

Goffman, E. (2002). A representação do eu na vida cotidiana (M. C. Santos Raposo, Trans.). Editora Vozes. (Original work published 1975)

Hall, S. (1993). Culture, community, nation. Cultural Studies, 7(3), 349-363. https://doi. org/10.1080/09502389300490251

Hall, S. (2006). A identidade cultural na pós-modernidade (T. T. da Silva \& G. L. Louro, Trans.). DP\&A. (Original work published 1992)

Harvey, D. (2008). Condição pós-moderna (A. U. Sobral \& M. S. Gonçalves, Trans.). Loyola. (Original work published 1989)

Herschmann, M. M., \& Pegoraro, É. (2017). Efervescência criativa e cultura participativa steampunk no contexto brasileiro. In J. Maria, C. S. Fernandes, C. L. R. Helal, \& E. Biachi (Eds.), Comunicação, arte e cidade: Experiências sensíveis e a produção de sentidos (pp. 82-94). LiquidBook. http://www.ppgcom.uerj.br/wp-content/uploads/E-Book-CAC.pdf

Higgins, L. (2012). Community music: In theory and in practice. Oxford University Press.

Janotti, J. Jr. (Ed.). (2013). Comunicações e territorialidades: Cenas musicais. Anadarco.

Janotti, J., Jr., \& Pires, V. A. N. (2011). Entre os afetos e os mercados culturais: As cenas musicais como formas de mediatização dos consumos musicais. In J. Janotti, Jr., T. R. Lima, \& V. A. N. Pires (Eds.), Dez anos a mil: Mídia e música popular massiva em tempos de internet (pp. 8-22). Simplíssimo.

Maffesoli, M. (1998). O tempo das tribos: O declínio do individualismo nas sociedades de massa (M. de L. Menezes, Trans.). Forense Universitária. (Original work published 1988)

Martín-Barbero, J. (1997). Dos meios às mediações: Comunicação, cultura e hegemonia. Editora UFRJ.

McKay, G., \& Higham, B. (2012). Community music: History and current practice, its constructions of "community", digital turns and future soundings. International Journal of Community Music, 5(1), 91-103. https://doi.org/10.1386/ijcm.5.1.91_1

Mocellim, A. D. (2010). A comunidade: Da sociologia clássica à sociologia contemporânea. Plural, 17(2), 105-128. https://doi.org/10.11606/issn.2176-8099.pcso.2010.74542

Orozco Gómez, G. (2005). O telespectador frente à televisão. Uma exploração do processo de recepção televisiva. Communicare, 5(1), 27-42. https://casperlibero.edu.br/wp-content/ uploads/2014/07/Communicare-vol.5.1.pdf 
Schechner, R. (2013). Performance studies: An introduction. Routledge.

Silver, D., \& Clark, T. (2016). Scenescapes: How Qualities of Place Shape Social Life. University of Chicago Press. https://doi.org/10.7208/9780226357041

Storey, J. (2003). Inventing popular culture: From folklore to globalization. Blackwell Publishing.

Straw, W. (1991). Systems of articulation, logics of change: Communities and scenes in popular music. Cultural Studies, 5(3), 368-388. https://doi.org/10.1080/09502389100490311

Straw, W. (2015). Some things a scene might be. Cultural Studies, 29(3), 476-485. https://doi.or g/10.1080/09502386.2014.937947

Veblen, K. K. (2008). The many ways of community music. International Journal of Community Music, 1(1), 5-21. https://doi.org/10.1386/ijcm.1.1.5/1

Welsch, W. (1999). Transculturality: The puzzling form of cultures today. In M. Featherstone \& S. Lash (Eds.), Spaces of culture: City, nation, world (pp. 194-213). Sage. 